\title{
Quantitative Localization of AMPA/Kainate and Kainate Glutamate Receptor Subunit Immunoreactivity in Neurochemically Identified Subpopulations of Neurons in the Prefrontal Cortex of the Macaque Monkey
}

\author{
J. C. Vickers, ${ }^{1}$, G. W. Huntley, ${ }^{1}$ A. M. Edwards, ${ }^{1}$ T. Moran, ${ }^{3}$ S. W. Rogers, ${ }^{4}$ S. F. Heinemann, ${ }^{5}$ and J. H. \\ Morrison ${ }^{1,2}$ \\ ${ }^{1}$ Fishberg Research Center for Neurobiology, ${ }^{2}$ Department of Geriatrics and Adult Development, and ${ }^{3}$ Hybridoma Facility, \\ the Mount Sinai School of Medicine, New York, New York 10029, ${ }^{4}$ Department of Pharmacology, University of Colorado \\ Health Science Center, Denver, Colorado 80262, and 5 Molecular Neurobiology Laboratory, The Salk Institute for Biological \\ Studies, La Jolla, California 92037
}

Excitatory amino acid transmission has been proposed as the principal synaptic mechanism for distribution of information through corticocortical and thalamocortical pathways. The following study utilized a double labeling paradigm, using antibodies that recognize non-NMDA ionotropic glutamate receptor subunits and other neuronal markers, to further define, quantitatively, the subclasses of neurons that contain immunoreactivity for the AMPA/kainate and kainate receptor subunits in the monkey prefrontal cortex. Double labeling with an antibody that recognizes common epitopes in AMPA/kainate subunits GluR2 and GluR3 (GluR2/3) in combination with an antibody that recognizes the kainate receptor subunits GluR5, GluR6, and GluR7 (GluR5/6/7) demonstrated that immunoreactivity for these two receptor classes was highly colocalized in a great majority of the pyramidal neurons in this region but present in only a minority of neurochemically identified subclasses of GABAergic interneurons. Furthermore, GluR2/3 immunoreactivity had principally a somatic distribution whereas GluR5/6/7 labeling was predominately found in the perikarya and/or particular dendritic domains. In contrast, intense GluR1 labeling was observed in a small subpopulation of interneurons and low GluR1 immunoreactivity was present in many other cortical neurons. These results demonstrate that there is a high degree of specificity in the distribution of AMPA/kainate and kainate receptor-class proteins to subclasses of neurons within the neocortex. A neuron's combination of excitatory amino acid receptor subunits may regulate its response to excitatory inputs and further defines the role of identified subclasses of neurons in the complex circuitry of the ce-

\footnotetext{
Received Oct. 23, 1992; revised Jan. 4, 1993; accepted Jan. 21, 1993.

This work was funded by the National Institute of Aging (AG06647) and the American Health Assistance Foundation. J.C.V. is a recipient of a C. J. Martin Postdoctoral Fellowship from the Australian National Health and Medical Research Council, and G.W.H. is an Aaron Diamond Foundation Fellow. We express our gratitude to Dr. R. J. Wenthold (NIH, Bethesda, MD) for provision of the antibodies to GluRs 1 and $2 / 3$ and to Dr. M. R. Celio (Universität Pérolles, Switzerland) for the antibodies to calcium-binding proteins. We also thank $R$. Woolley and $\mathbf{J}$. Woolley for assistance in preparation of the figures.

Correspondence should be addressed to Dr. J. H. Morrison, Fishberg Research Center for Neurobiology, Box 1065, Mount Sinai Medical Center, One Gustave L. Levy Place, New York, NY 10029-6574.

Copyright (C) 1993 Society for Neuroscience $0270-6474 / 93 / 132982-11 \$ 05.00 / 0$
}

rebral cortex and may also indicate the basis for the apparent cellular selectivity of excitotoxic degenerative processes.

[Key words: excitatory amino acids, glutamate, AMPA, kainate, receptors, neurofilaments, calcium-binding proteins, microtubule-associated proteins, primate, neocortex, colocalization studies]

The excitatory amino acids (EAAs) serve as the major excitatory ncurotransmitters in the CNS (Barncs and Henlcy, 1992; McCormick, 1992). Given the multiplicity of receptor subtypes that have been described for glutamate, a particular neuron's response to this excitatory neurotransmitter will be determined by the presence and organization of diverse receptor subunit proteins. Whereas, in earlier studies, particular glutamate agonists and antagonists were utilized for autoradiographic binding and pharmacological investigations, the recent identification of families of genes coding for ionotropic and metabotropic glutamate receptor (GluR) subunit proteins allows for the direct analytical localization of such receptor subunits in particular subsets of the postsynaptic neurons.

Multiple proteins appear to comprise the family of non-NMDA ionotropic GluRs. Cloning and functional expression studies have so far demonstrated that there are four subunits (GluRs 1-4 or A-D) that are optimally sensitive to AMPA but also respond to kainate (Hollman et al., 1989; Keinänen et al., 1989; Boulter et al., 1990; Nakanishi et al., 1990; Sommer et al., 1990) and five subunits (GluRs 5-7, KAl and KA2) that represent kainate-binding proteins that may form functional receptors in various combinations (Bettler et al., 1990, 1992; Egebjerj et al., 1991; Werner et al., 1991; Sommer and Seeburg, 1992; Sommer et al., 1992).

The development of antibodies to these proteins made it possible to localize these subunits to particular neurons. For example, Petralia and Wenthold (1992) have utilized single labeling immunohistochemistry to investigate which subsets of cells in the rat CNS contain GluRs $1-4$. We recently demonstrated that immunoreactivity with an antibody that recognizes a common epitope in GluRs 5-7 is also present in specific subsets of cortical neurons and has a high degree of regional and laminar selectivity in the monkey neocortex (Huntley et al., 1993). Such regional and laminar patterns not only may reveal important patterns of distribution that can be linked to partic- 
Table 1. Primary antibodies

\begin{tabular}{lllll} 
Code & Type & Dilution & Immunoreactivity & Source \\
\hline 4F5 & M IgM & $1: 500$ & GluR5/6/7 & $\begin{array}{l}\text { J. H. Morrison, S. W. Rogers, } \\
\text { and S. F. Heinemann }\end{array}$ \\
Ab25 & R IgG & $1: 100$ & GluR2/3 & $\begin{array}{l}\text { R. J. Wenthold } \\
\text { Ab9 }\end{array}$ \\
R IgG & $1: 100$ & GluR1 & R. J. Wenthold \\
HM-2 & M IgG & $1: 500$ & MAP2 & Sigma Immunochemicals \\
SMI32 & M IgG & $1: 5000$ & NF proteins & Sternberger Monoclonals, Inc. \\
300 & M IgG & $1: 2000$ & Calbindin & M. R. Celio \\
7696 & R IgG & $1: 3000$ & Calretinin & M. R. Celio \\
235 & M IgG & $1: 2000$ & Parvalbumin & M. R. Celio \\
9064 & R IgG & $1: 2000$ & Parvalbumin & M. R. Celio
\end{tabular}

$\mathrm{M}$, Mouse; $\mathrm{R}$, rabbit.

ular circuits and functions but also may be relevant to apparent selective vulnerability in neurodegenerative disorders that involve EAA excitotoxic mechanisms. The present study utilized antibodies that recognize either GluR 1 , a common epitope in GluR2 and GluR3 (GluR2/3), or a common epitope in GluR5, GluR6, and GluR7 (GluR5/6/7) in combination with neuronal markers for specific subsets of cortical neurons, such as the cytoskeletal proteins MAP2 and the neurofilament (NF) triplet for pyramidal cells, and the calcium-binding proteins calbindin, calretinin, and parvalbumin for subclasses of GABAergic interneurons, to determine which neuronal subclasses in the monkey prefrontal cortex contain these receptor proteins. These data make it possible to integrate the pattern of GluR subunit distribution into a more comprehensive profile of the neurochemical phenotype of neocortical neurons in the primate brain.

\section{Materials and Methods}

Animals and tissue processing. Tissue from a total of 10 cynomolgus monkeys (Macaca fascicularis) was utilized for this study. All procedures relating to the care and treatment of animals conformed to institutional and NIH guidelines. Animals were anesthetized with ketamine hydrochloride $(25 \mathrm{mg} / \mathrm{kg}$, i.p.) and sodium pentobarbital $(20 \mathrm{mg} / \mathrm{kg}$, i.v.). Following opening of the chest cavity, $2.0 \mathrm{ml}$ of $1 \%$ sodium nitrite was injected into the left ventricle, the descending aorta was clamped, and the animal was perfused transcardially through the left ventricle for $30-$ $60 \mathrm{sec}$ with ice-cold $1 \%$ paraformaldehyde [in a phosphate $(100 \mathrm{~mm})$ buffered saline $(75 \mathrm{~mm})$ solution] followed by cold $4 \%$ buffered paraformaldehyde for $8-10 \mathrm{~min}$. The brains were removed and postfixed in cold $4 \%$ buffered paraformaldehyde for a total of $6 \mathrm{hr}$ from the beginning of the perfusion. The tissue was then cleared of fixative and cryoprotected through a series of graded sucrose solutions $(12 \%, 16 \%$, and $18 \%)$. Coronal blocks of the frontal cortex were sectioned $(40 \mu \mathrm{m})$ on a cryostat.

Antibody characterization. Tables 1 and 2 present the primary and secondary antibodies used in this study, respectively. The antibodies to GluRs 1 and $2 / 3$ used were polyclonal sera raised against synthetic peptides corresponding to the C-terminus domains of these proteins and have been characterized previously (Wenthold et al., 1990, 1992;
Petralia and Wenthold, 1992). The antibody to the GluR5/6/7 is a mouse monoclonal antibody of the IgM type raised against a fusion protein corresponding to the N-terminal domain of GluR5. Further characterization by radioimmunoassay and Western blots, as well as immunohistochemistry on kidney 293 cells transfected with various GluR subunits, has demonstrated that this antibody recognizes a common epitope in GluR 5, GluR6, and GluR7 (Huntley et al., 1993).

Immunohistochemistry. For optimal immunolocalization of receptor subunits, tissue sections were treated for $1 \mathrm{hr}$ in a $10 \%$ dimethyl sulfoxide solution followed by an additional freeze-thawing with liquid nitrogen (see Huntley et al., 1993). All antibodies were diluted in a phosphatebuffered saline solution containing $0.3 \%$ Triton and $5 \%$ nonfat milk powder. Single labeling preparations for antibodies to GluR 1, GluR2/3, and GluR5/6/7 were processed using species-specific Vectastain ABC immunoperoxidase kits (Vector Labs, Burlingame, CA). For immunofluorescence studies, all possible appropriate double labeling combinations of primary (i.e., mouse $\mathrm{IgG}$ with mouse $\mathrm{IgM}$, mouse $\mathrm{IgG}$ with rabbit IgG, mouse IgM with Rabbit IgG) and secondary antibodies were used. Control preparations consisted of the omission of either primary antibodies or secondary antibodies at appropriate stages. The secondary antibodies used for these combinations were free of undue cross-reactivity at the dilutions used. Preparations were viewed with a Zeiss Axiophot fluorescence photomicroscope equipped with filter blocks for the selcctive visualization of fluorescein isothiocyanate and Texas red, respectively. Photographs were taken using Kodak TMAX 400 blackand-white film rated at 1000 ASA.

Quantitative analysis. Quantitative analyses were performed on double-labeled sections of the dorsolateral prefrontal cortex, medial to the principal sulcus (Brodmann area 9) using the fluorescence photomicroscope equipped with an MSP 65 computer-driven stage, a high-sensitivity CCD camera, and a DECstation 3100 computer with morphometry software developed in our laboratory in collaboration with the Scripps Research Institute (La Jolla, CA). Images were captured, using the $40 \times$ Neofluar objective, in series encompassing entire traverses of the cortical layers. The locations of cells containing overlapping and nonoverlapping markers were mapped using this system. Five traverses were analyzed from each double labeling combination involving glutamate receptor markers for GluR2/3 and GluR5/6/7 in matcrial from four animals. Thus, for each of these analyses a total of 20 traverses (approximately 1300-3300 cells, dependent on density of marker) were quantified for each double labeling preparation.

\section{Table 2. Secondary antibodies}

\begin{tabular}{llll} 
Immunoreactivity & Conjugate & Raised in & Used with \\
\hline M IgG (H and L chains) & FITC & Horse & SMI32, MAP2, Calb, Parv \\
M IgG ( $\gamma$-chain) & FITC & Horse & SMI32, MAP2, Calb, Parv \\
M IgM ( $\mu$-chain) & Biotin & Goat & GluR5/6/7 \\
M IgM ( $\mu$-chain) & Texas red & Goat & GluR5/6/7 \\
R IgG & Biotin & Goat & GluR2/3, Calret, Parv
\end{tabular}


Figure 1. Immunoperoxidase labeling for GluR 1 and GluR2/3 epitopes in layers III $(A, B)$ and $\mathrm{V}(C, D)$ of the monkey prefrontal cortex. $A$ shows an example of GluR1 immunolabeling in layer III, with a small group of cortical neurons showing relatively intense labeling (arrows). Conversely, many neurons in layer $\mathrm{V}(C)$ show GluR1 immunoreactivity. Neurons in layers III $(B)$ and $\mathrm{V}(D)$ of the prefrontal cortex also contain neurons immunoreactive for GluR2/3. Scale bar, $25 \mu \mathrm{m}$.
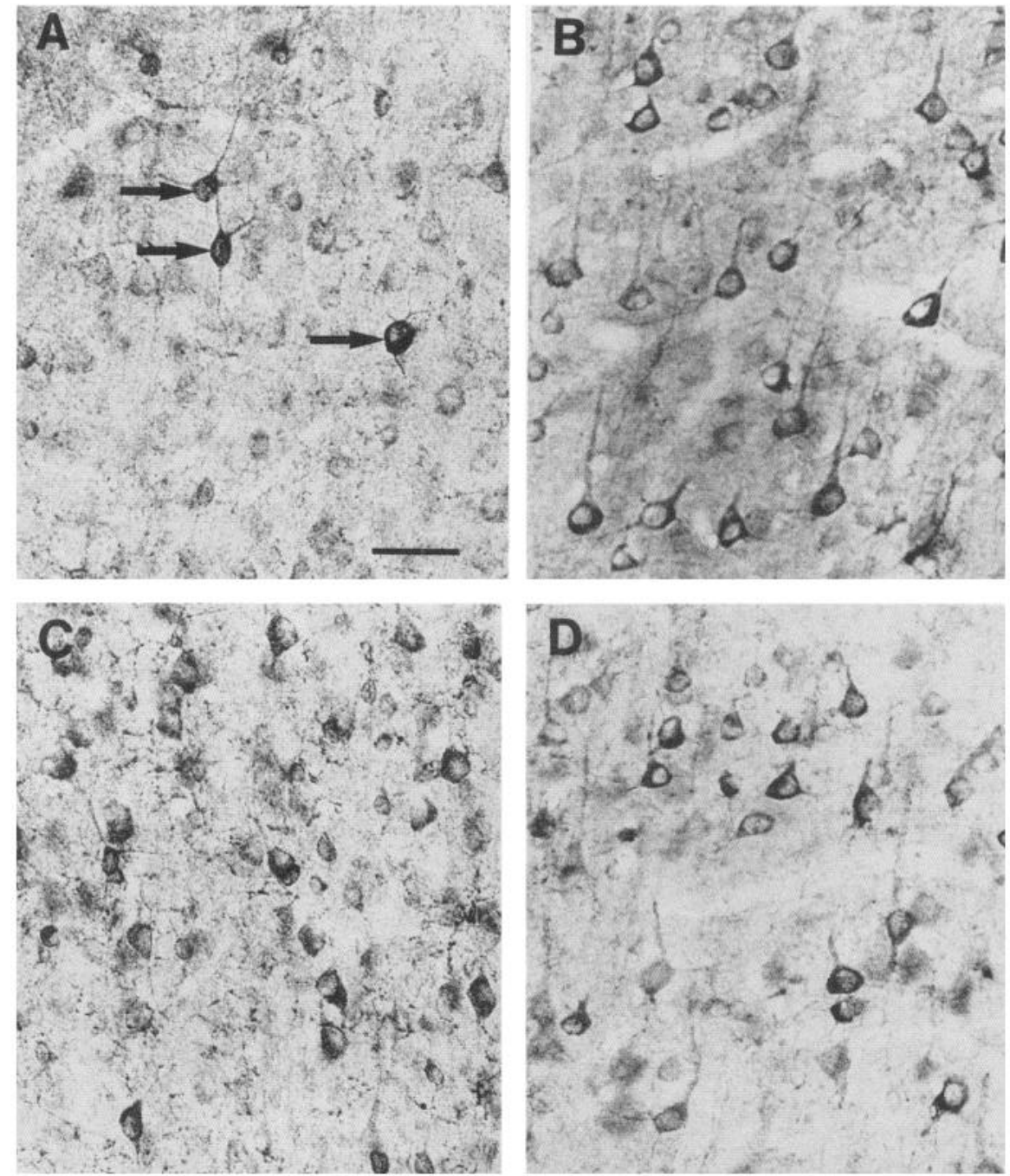

An estimate of the degree of overlap between the NF triplet, calbindin, calretinin, and parvalbumin markers was established by examining the extent of colocalization from representative samples (100 cells) of each marker in a double-labeled section from each animal.

\section{Results}

\section{Distribution of GluR subunits}

In monkey prefrontal cortex (area 9), intense GluR5/6/7 immunoreactivity was present in nerve cell bodies located in layers II, III, and V and in long apical dendrites extending from layer $\mathrm{V}$ through layers IV and III and also in the shorter apical dendrites of layer II and III neurons (see Huntley et al., 1993). GluR5/6/7 labeling in apical dendrites was often localized to small punctate concentrations of immunoreactivity. Less intense GluR5/6/7 labeling was also found in relatively smaller cell bodies in all layers.

Immunoreactivity for GluR $2 / 3$ and GluR 1 in area 9 of the monkey neocortex was very similar to that previously demonstrated in the rat neocortex (Petralia and Wenthold, 1992). For example, in this monkey neocortical area, faint to moderate GluR1 immunoreactivity was present in many cells in layers IV-VI and moderate to intensely labeled small cells were sparsely distributed in layers II and III (Fig. 1A,C). These latter cells often had many fine dendritic processes and lacked a distinct apical dendrite and therefore may correspond to nonpyramidal cells. Faint immunoreactivity for GluR 1 was also detected in some cells that may correspond to glial cells in the deep cortical layers and underlying white matter. Many cell bodies in layers II, III, and V were intensely immunoreactive for GluR2/3, whereas smaller cell bodies in all layers showed faint immunoreactivity (Fig. $1 B, D$ ). GluR2/3 immunoreactivity rarely extended past the most proximal regions of dendritic processes.

\section{Colocalization of GluR subunits and neuronal markers}

Table 2 summarizes the quantitative data on the immunohistochemical colocalization of GluR subunits with each other and other neuronal markers derived from immunofluorescence preparations. Specific fluorescence for antibodies to neuronal markers was ascertained by comparisons with control preparations. Lipofuscin autofluorescence could be distinguished from antibody-specific fluorescence by its cellular location, morphology, and fluorescent properties with multiple filter blocks. Examples of the maps of cortical traverses showing colocalization of immunoreactivity for these markers used to generate the quantitative data are shown in Figure 2.

GluR 5/6/7, GluR2/3, and GluR1. Double labeling for GluR5/ $6 / 7$ and GluR $2 / 3$ demonstrated that $69.9 \%(\mathrm{SD}=3.8)$ of the GluR2/3-labeled cell bodies showed immunoreactivity for 
GluR5/6/7, whereas all GluR5/6/7-immunoreactive cell bodies were also immunoreactive for GluR2/3 (Figs. $2 A, 3$ ). Double labeling also demonstrated that there were pyramidal-like neurons that showed GluR 5/6/7 and GluR2/3 immunoreactivity in neuronal perikarya but only GluR 5/6/7 labeling in more distal apical dendritic segments. Nerve cell bodies showing GluR2/3 immunoreactivity but not GluR5/6/7 labeling were found throughout layers II-VI.

Due to the low intensity of fluorescent labeling for GluR I in double-labeled preparations, detailed quantitative analyses of its colocalization with other neuronal markers were not conducted. However, many of the GluR 5/6/7-labeled cells in layers IV-VI were also faintly immunoreactive for GluR I, but not all the GluR 1 cells in these regions showed immunoreactivity for GluR5/6/7. In particular, glial-like cells labeled for GluR1 lacked immunoreactivity for GluR5/6/7. Approximately $20-25 \%$ of the sparsely distributed cells in layers II and III that showed relatively intense immunoreactivity for GluR 1 were also faintly immunoreactive for GluR5/6/7. GluR5/6/7 immunoreactivity was present only in the perikarya of these cell bodies and did not extend into the dendritic processes labeled for GluR1.

GluR subunits and cytoskeletal protein markers. Antibodies to MAP2 were utilized to label both cell bodies and dendrites. As previously demonstrated in monkey neocortex (Peters and Sethares, 1991), large cells that were likely to correspond to pyramidal cells were intensely labeled for MAP2 whereas smaller cells were faintly immunoreactive. Double labeling for MAP2 with GluR2/3 or GluR 5/6/7 indicated that these three neuronal markers were likely to label the majority of neurons in the monkey prefrontal cortex (Fig. 4). Furthermore, most, but not all, apical dendrites intensely labeled for MAP2 were also immunoreactive for GluR 5/6/7. Double labeling also demonstrated that GluR5/6/7 labeling along apical dendrites could be discontinuous in that GluR5/6/7 immunoreactivity was unevenly distributed along some apical dendrites that extended from layer III to V. In addition, some of the MAP2-immunoreactive pyramidal cell-like perikarya in layers III and $\mathrm{V}$ that were not labeled for GluR5/6/7 gave rise to apical dendrites that were immunoreactive for GluR5/6/7. Double labeling for GluR2/3 and MAP2 further demonstrated that little GluR2/3 labeling is present in dendrites.

SMI32, an antibody that recognizes nonphosphorylated isoforms of the two higher-molecular-weight NF triplet proteins (Sternberger and Sternberger, 1983; Lee et al., 1988), has been previously shown to label a subpopulation of pyramidal cells in the monkey neocortex (Campbell and Morrison, 1989). Similarly, in the monkey prefrontal cortex, this antibody intensely labeled pyramidal cells in layers III and V. Other cells in layers II and VI demonstrated faint to moderate labeling. Double labeling for GluR2/3 and SMI32 demonstrated that all SMI32labeled cell bodies were also GluR2/3 immunoreactive and confirmed that GluR2/3 labeling was minimal beyond the proximal dendritic regions of SMI32-labeled neurons (Fig. 5, Table 3).

Double labeling for GluR5/6/7 and SMI32 (Figs. 2B,6; Table 3) demonstrated that $31.3 \%(\mathrm{SD}=3.1)$ of GluR5/6/7-labeled cell bodies were labeled for SMI32 and $86.3 \%(\mathrm{SD}=1.9)$ of SMI32-labeled cell bodies were immunoreactive for GluR5/6/ 7. However, a further $3.9 \%(\mathrm{SD}=1.4)$ of SMI32-labeled neurons showed GluR5/6/7 immunoreactivity in their proximal apical dendrite and not in the SMI32-labeled cell body. Examination of the colocalization of SMI32 and GluR5/6/7 labeling also showed that some SMI32 neurons only had GluR5/6/7 labeling
A

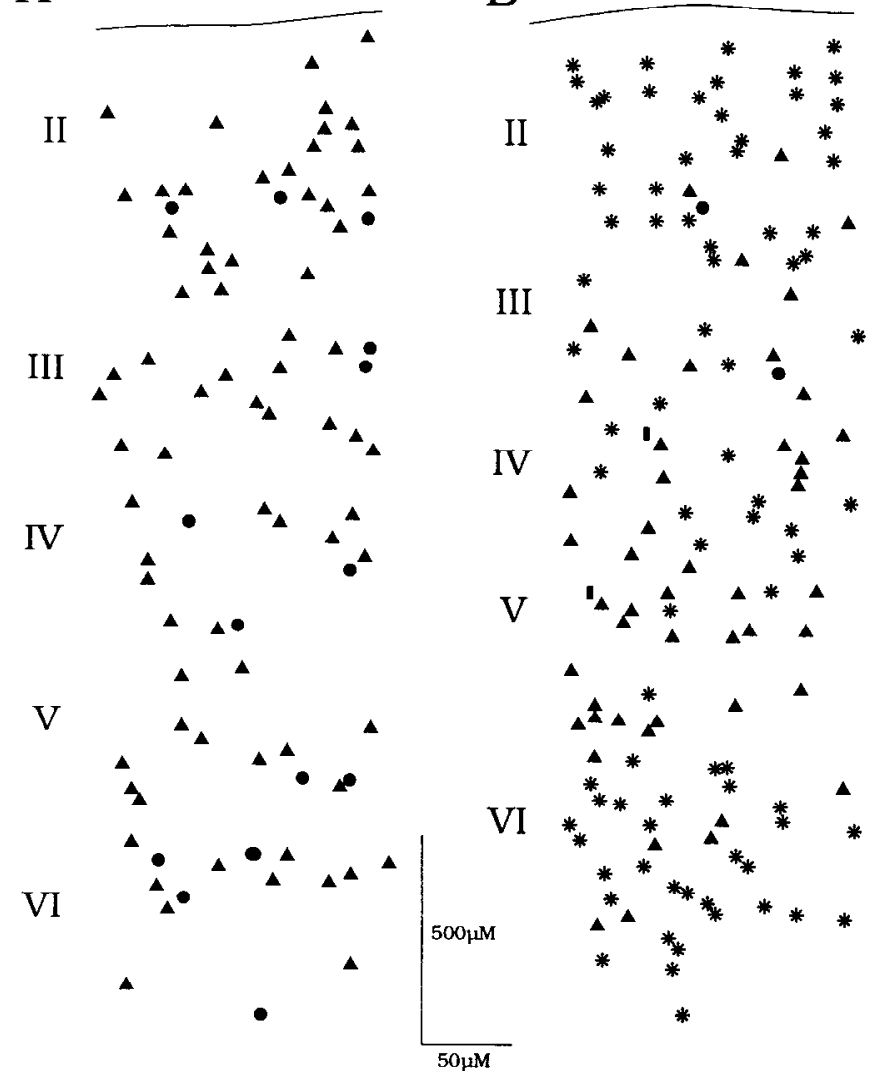

Figure 2. Examples of maps of cortical traverses, derived from captured digital images and custom morphometry software, demonstrating double labeling for GluR $2 / 3$ with GluR5/6/7 $(A)$ and GluR5/6/7 with nonphosphorylated NF protein $(B)$. In $A$, triangles show the location of cell bodies double labeled for GluR $2 / 3$ and GluR5/6/7, whereas circles demonstrate the location of cell bodies showing labeling for GluR $2 / 3$ but not GluR 5/6/7. In $B$, triangles show NF-labeled cell bodies that contain GluR5/6/7 labeling, vertical bars show NF-labeled neurons that lack GluR5/6/7 labeling in the cell body but contain GluR labeling in the proximal segment of the apical dendrite, circles show NF-labeled cell bodies that lack GluR $5 / 6 / 7$ labeling in either their cell body or proximal apical dendrite, and asterisks show GluR5/6/7-labeled cell bodies that lack labeling for NF proteins.

in more distal dendritic segments. GluR 5/6/7 labeling can also be found in branches extending from the apical dendrite and that the GluR 5/6/7 labeling is often more extensive in some basal dendrites than other basal dendrites of the same pyramidal neuron. GluR5/6/7-immunoreactive neurons that often had a pyramidal cell-like morphology but lacked labeling with SMI32 were particularly abundant in layer II and the superficial regions of layer III. Other GluR5/6/7-immunoreactive cells without SMI32 labeling were prevalent in layers IV and VI.

Many of the SMI32-labeled cells showed faint immunoreactivity for GluR1, particularly the neurons located in layers $\mathrm{V}$ and VI. None of the relatively well-labeled GluR 1-immunoreactive cells in layers II and III showed immunoreactivity with SMI32.

GluR subunits and calcium-binding protein markers. Double labeling with the calcium-binding proteins parvalbumin, calretinin, and calbindin demonstrated that each of these markers labeled distinct subpopulations of neurons within the macaque prefrontal cortex. Furthermore, a small proportion of both the calretinin-immunoreactive cells located in layers V and VI and 

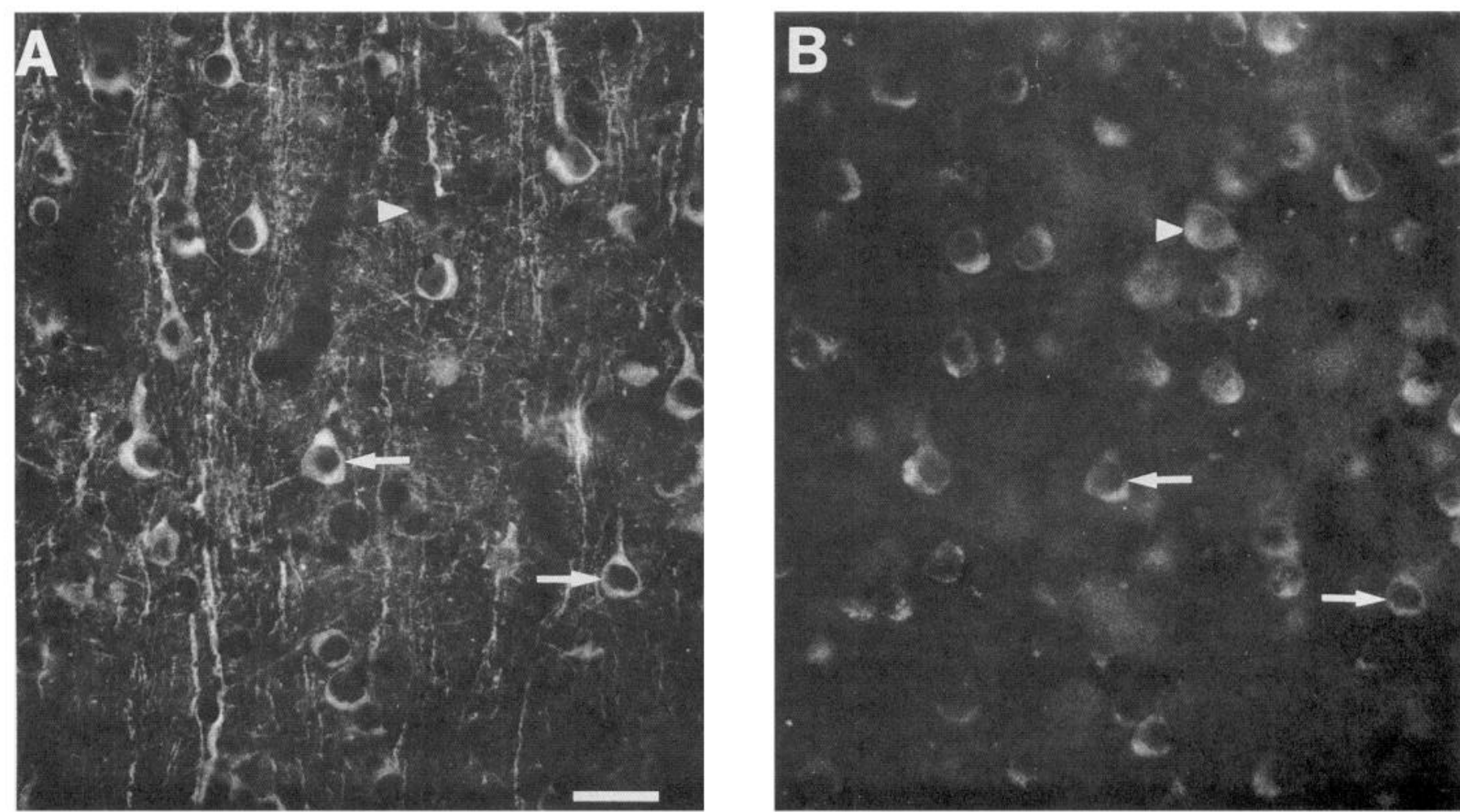

Figure 3. Double labeling for GluR5/6/7 $(A)$ and GluR2/3 $(B)$ in superficial layer III of the prefrontal neocortex. Most cell bodies show labeling for the GluR5/6/7 and GluR2/3 (e.g., arrows) but some cell bodies are immunoreactive for GluR2/3 and not GluR5/6/7 (arrowheads). Note that the GluR5/6/7 antibody labels nerve cell bodies and apical dendrites whereas the antibody to GluR2/3 labels cell bodies preferentially. Scale bar, $25 \mu \mathrm{m}$.
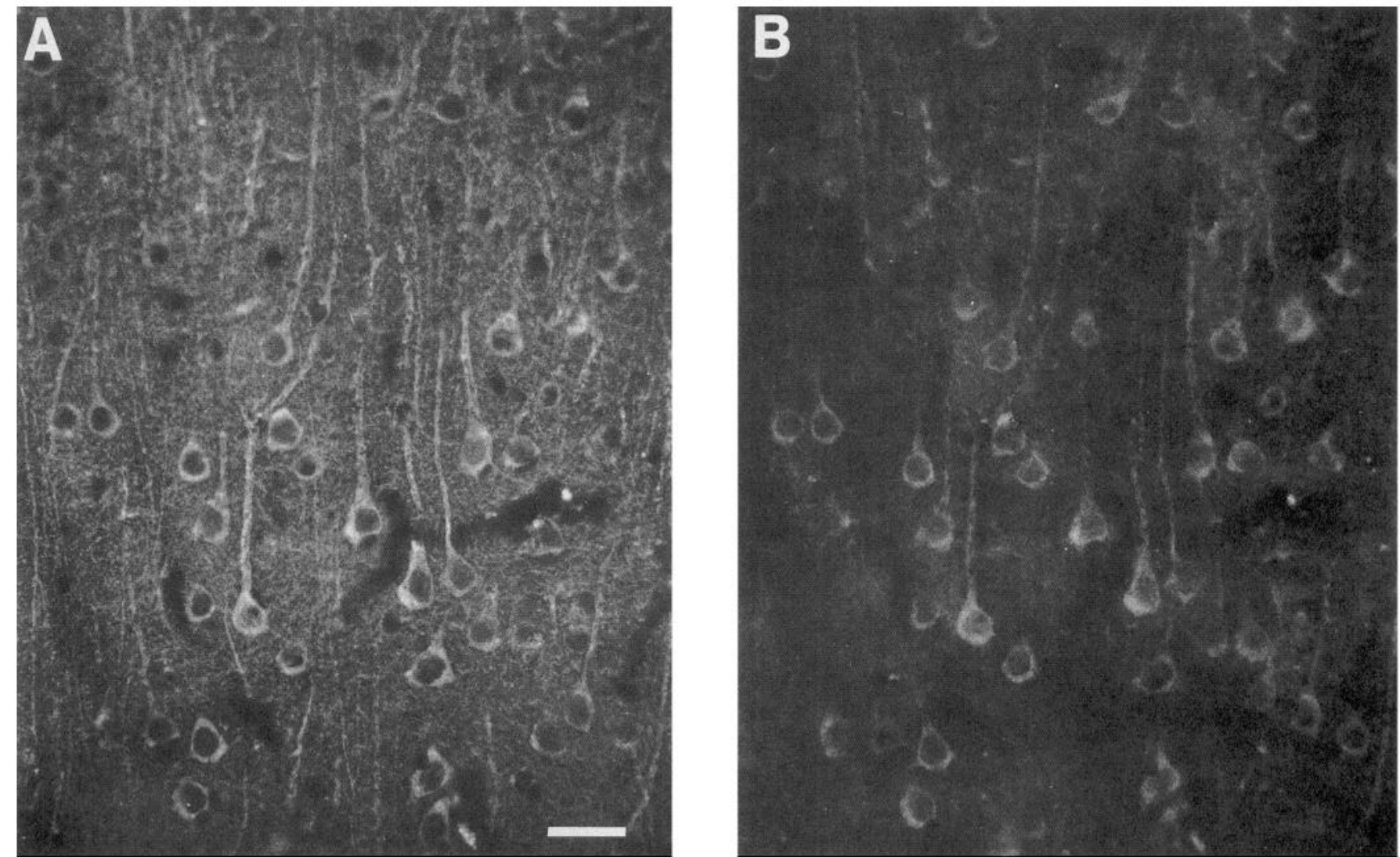

Figure 4. Double labeling for MAP2 $(A)$ and the GluR5/6/7 $(B)$ in layer III of the prefrontal neocortex. Many of the cell bodies and apical dendrites well labeled for MAP2 are also immunoreactive for GluR5/6/7. Scale bar, $25 \mu \mathrm{m}$. 

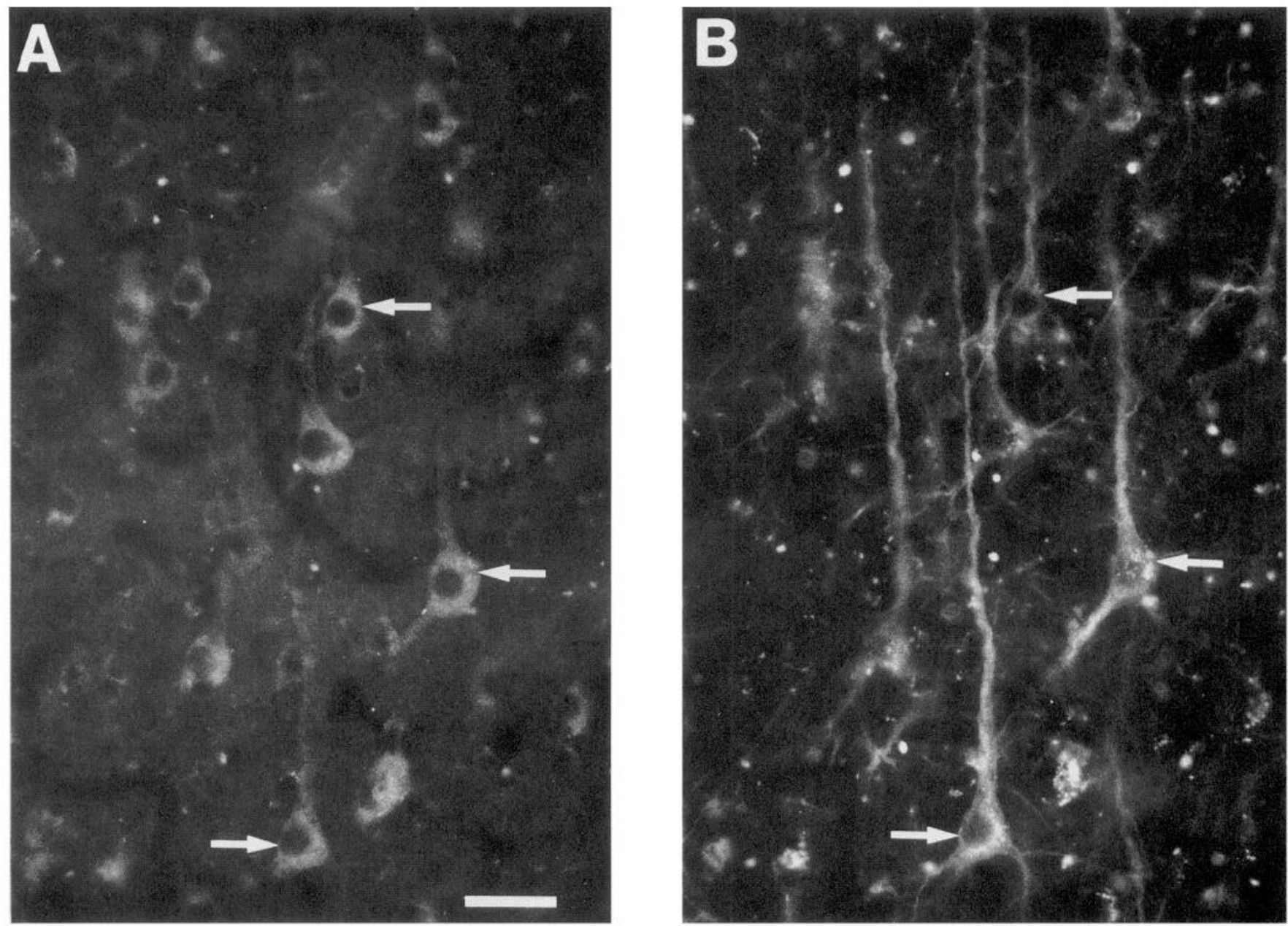

Figure 5. Double labeling for GluR2/3 $(A)$ and nonphosphorylated NF protein $(B)$ in layer III of the prefrontal cortex. Many, but not all, pyramidal neurons labeled for the NF proteins are also immunoreactive for GluR2/3 (e.g., arrows). Scale bar, $25 \mu \mathrm{m}$.

the parvalbumin-labeled cells in layers III-V showed faint to moderate immunoreactivity with SMI32 (Table 3).

Calretinin-labeled small cells with a bipolar or bitufted morphology were predominately located in layer II but labeled cells were also present in layers III-VI. Double labeling for calretinin and GluR5/6/7 demonstrated that less than $1 \%$ of calretininlabeled neurons showed faint immunoreactivity for GluR5/6/ 7. Calbindin-labeled cells were also abundant in layer II and in scattered cells in layers III-VI and thus are likely to correspond to double bouquet cells, as previously described (DeFelipe et al., 1989a). Double labeling for calbindin with GluR5/6/7 or GluR2/3 demonstrated that $31.4 \%(\mathrm{SD}=7.8)$ and $28.1 \%(\mathrm{SD}$ $=4.8$ ) of calbindin-immunoreactive cells were labeled for GluR5/ 6/7 and GluR2/3, respectively (Table 3). Such double-labeled cells often showed only faint immunoreactivity to the GluR subunit antibodies and these corresponded to a very minor proportion of the total number of neurons labeled for GluR 5/6/7 and/or GluR2/3 (Table 3). Calbindin-immunoreactive neurons containing GluR 5/6/7 or GluR2/3 labeling did not have a discrete, specific laminar distribution, but rather were distributed

\begin{tabular}{|c|c|c|c|c|c|c|}
\hline & GluR2/3 & GluR5/6/7 & SMI32 & Parvalbumin & Calbindin & Calretinin \\
\hline GluR 2/3 & - & $69.9 \pm 3.8$ & $32.2 \pm 0.7$ & $2.9 \pm 0.2$ & $1.7 \pm 0.2$ & $<1^{* *}$ \\
\hline GluR 5/6/7 & 100 & - & $31.3 \pm 3.1$ & $5.9 \pm 1.6$ & $2.4 \pm 1.4$ & $<1$ \\
\hline SMI32 & 100 & $86.3 \pm 1.9$ & - & $<5^{*}$ & N.P. & $<2 *$ \\
\hline Parvalbumin & $32.3 \pm 1.8$ & $50.0 \pm 11.0$ & $8-10^{*}$ & - & $0^{*}$ & $0^{*}$ \\
\hline Calbindin & $28.1 \pm 4.8$ & $31.4 \pm 7.8$ & N.P. & $0^{*}$ & - & $0^{*}$ \\
\hline Calretinin & $<1^{* *}$ & $<1$ & $<5^{*}$ & $0^{*}$ & $0^{*}$ & - \\
\hline
\end{tabular}

Data are means \pm SD. * Estimates based on samples of 400 cells for each marker (see Materials and Methods). ${ }^{* *}$, Extrapolated data. N.P., not possible to evaluate given present antibody combinations. 

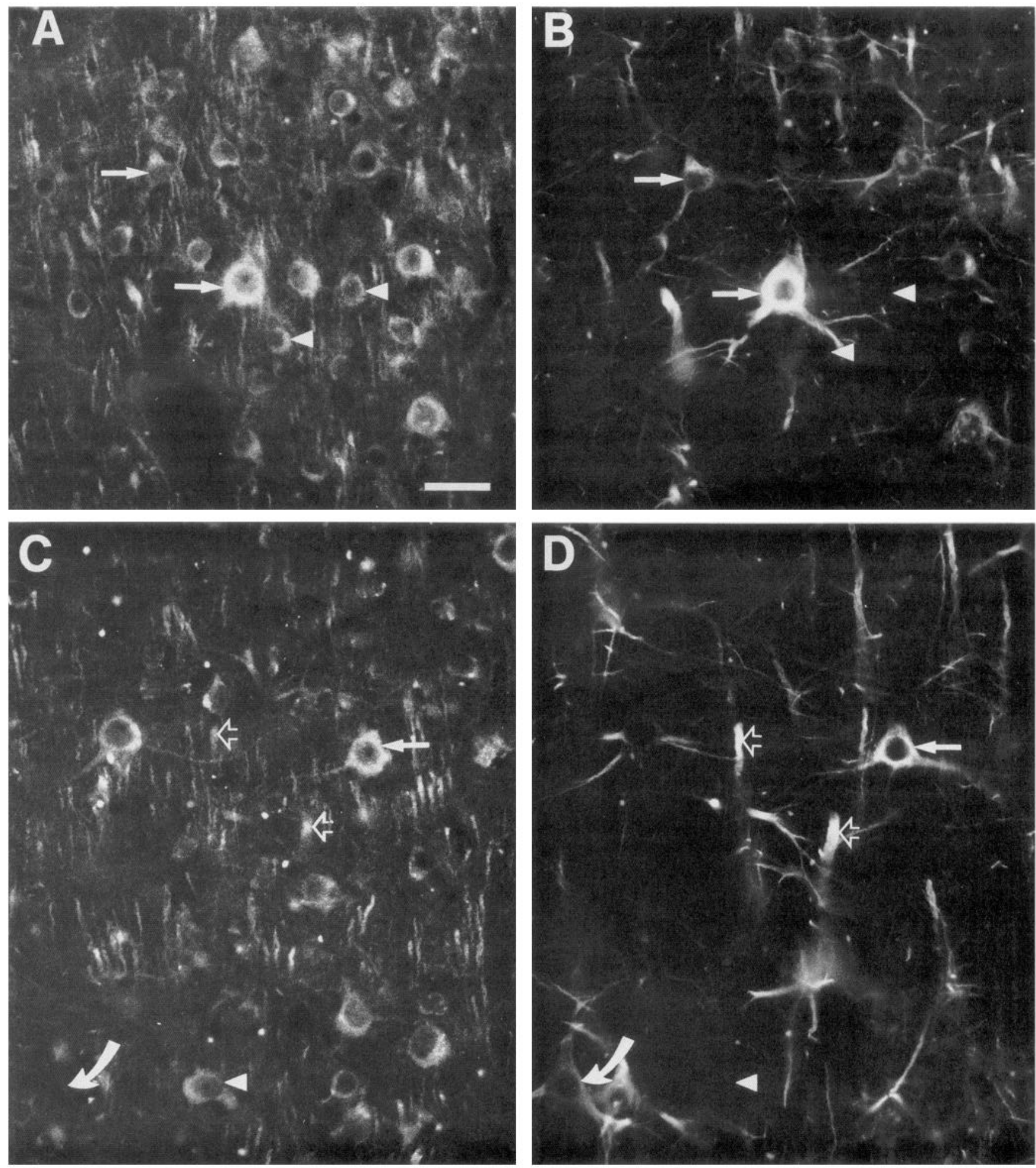

Figure 6. Double labeling for GluR5/6/7 $(A, C)$ and nonphosphorylated NF protein $(B, D)$ in layer III of the prefrontal cortex. Arrows show examples of cell bodies containing both GluR5/6/7 immunoreactivity and labeling for NF proteins. Arrowheads demonstrate examples of GluR5/ 6/7-labeled cells with no labeling for NF proteins and, conversely, the curved arrow shows an NF protein-labeled cell body with no immunoreactivity for GluR5/6/7. Open arrows show colocalization of GluR5/6/7 and NF protein immunoreactivity in apical dendrites. Scale bar, $25 \mu \mathrm{m}$.

throughout the same laminae that contained calbindin-immunoreactive neurons that lacked GluR2/3 or GluR5/6/7 labeling.

Parvalbumin immunoreactivity was present in small to large neurons in layers II-VI, many of which would correspond to chandelier and basket cells (DeFelipe et al., 1989b; Hendry et al., 1989). The proportion of parvalbumin-labeled cells that showed GluR5/6/7 or GluR2/3 immunoreactivity was $50.0 \%$ $(\mathrm{SD}=11.0)$ and $32.5 \%(\mathrm{SD}=1.8)$, respectively (Table 3$)$. In a similar fashion to the calbindin-immunoreactive cells, most of the parvalbumin cells that were immunoreactive with GluR 
antibodies were only faintly immunoreactive for GluR $2 / 3$ or GluR5/6/7 in the cell body with little immunoreactivity in emerging dendrites. A subpopulation of the large parvalbuminimmunoreactive cells showed greater intensity of labeling for GluR 2/3 or GluR5/6/7, with GluR5/6/7 immunoreactivity extending into the primary, and often the secondary, dendrites of these neurons.

Approximately $5-10 \%$ of the small cells intensely immunoreactive for GluR1 in layers II and III were immunoreactive for either parvalbumin or calbindin. Many of the parvalbuminimmunoreactive cells showed faint immunoreactivity for GluR1.

\section{Discussion}

Selective distribution and colocalization of GluR subunits

The present results demonstrate that GluR1, GluR2/3, and GluR 5/6/7 epitopes have a specific cellular distribution within the prefrontal cortex. Furthermore, these GluR subunits show different degrees of colocalization within particular neurons and cellular compartments. Neuronal subpopulations within the neocortex may therefore be delineated by their immunoreactivity for specific combinations of receptor subunits. In addition, by analyzing the codistribution of GluR subunits with other markers selective for cytoskeletal or calcium-binding proteins, the GluR profile can be linked to other aspects of neurochemical phenotype that display extensive neuronal selectivity.

While the GluR2/3 and GluR5/6/7 antibodies are cross-reactive for multiple subunits within the AMPA/kainate and kainate receptor-class subunits, respectively, the present data give an indication of which cells contain particular GluR subunits and, to some degree, the cellular compartmentalization of the detectable epitopes. Single and double labeling studies showed that GluR5/6/7 and GluR2/3 epitopes were present predominately in neurons that correspond to pyramidal cells located in layers II, III, V, and VI. These two markers show a high degree of colocalization in cell bodies with $100 \%$ of the GluR5/6/7immunoreactive perikarya showing GluR2/3 labeling and approximately $70 \%$ of the GluR $2 / 3$ perikarya showing GluR5/6/ 7 labeling. In contrast, GluR5/6/7 labeling was also present in apical dendrites and to some extent in basal dendrites, whereas GluR2/3 labeling was present only in cell bodies and the proximal segment of apical dendrites.

All of the pyramidal cells that contained the marker SMI32, an antibody that labcls nonphosphorylated forms of two subunits of the NF triplet, also showed labeling for GluR2/3. In contrast, approximately $85 \%$ of the SMI32-labeled neurons showed GluR5/6/7 immunoreactivity in their cell bodies. A further $4 \%$ of SMI32-labeled neurons lacked GluR 5/6/7 labeling in their cell bodies but did contain immunoreactivity for these subunits in the proximal segment of the apical dendrites. A minor subpopulation of SMI32-labeled neurons contained GluR 5/6/7 immunoreactivity in more distal dendritic segments. Coupled with the observation that GluR5/6/7 labeling can be segmented along apical dendrites (present study; Huntley et al., 1993), these results show that the GluR 5/6/7 epitope has a specific cellular localization within the particular neurons in which it is contained. Furthermore, these observations indicate that a greater proportion of the GluR2/3-labeled cells contained the GluR5/6/7 subunit than indicated by the quantitative assessment of overlap of these markers in the perikarya. In addition, both GluR $2 / 3$ and GluR5/6/7 subunits are clearly present in a class of pyramidal neurons that is broader but inclusive of the pyramidal cells labeled with SMI32.
The presence of GluR immunoreactivity in subsets of GABAergic interneurons was established in double labeling experiments utilizing the calcium-binding protein markers calretinin, parvalbumin, and calbindin (DeFelipe et al., 1989a,b; Hendry et al., 1989). In the monkey prefrontal cortex, antibodies to calretinin, parvalbumin, and calbindin labeled separate subpopulations of interneurons and further minor subclasses of these neurons were labeled with the NF triplet antibody SMI32. Virtually none of the interneurons containing calretinin were either GluR2/3 or GluR 5/6/7 immunoreactive, whereas approximately $30-50 \%$ of the parvalbumin- and calbindin-labeled cells were immunoreactive for these receptor subunits. By extrapolation from the high degree of colocalization of GluR 5/6/ 7 and GluR2/3 immunoreactivity in neuronal perikarya, the great majority of the parvalbumin or calbindin cells that were immunoreactive for these GluR subunits are likely to contain both GluR2/3 and GluR5/6/7 labeling. However, GABAergic interneurons are likely to account for a small proportion of the neurons containing GluR2/3 or GluR5/6/7 immunoreactivity in this cortical region.

GluR1 labeling also had a distinct distribution in the neocortex with faint labeling in cells in the deeper layers and intense immunoreactivity in a small number of cells in layers II and III. Although quantification of the overlap of neuronal markers and other GluR subunits in cells in the deeper layers was not possible due to the low intensity of immunoreactivity with GluR 1, the great majority of the SMI32- and GluR5/6/7-labeled neurons in these layers also contained GluR 1 labeling. The small cells in layers II and III that were intensely labeled for GluR 1 are likely to correspond to interneurons and minor subpopulations of these contained immunoreactivity for either parvalbumin or calbindin and also GluR5/6/7 and, by extrapolation, GluR2/3. GluR 1 is also a possible candidate for a subunit component of GluRs on glial cells (Zorumski and Thio, 1992).

Immunoreactivity for these GluR subunits appears to be present in both the cytoplasm and postsynaptic densities in the macaque and rat neocortex, as has been confirmed by immunoelectron microscopy (Petralia and Wenthold, 1992; Huntley et al., 1993). These antibodies may therefore be recognizing either a cytoplasmic pool of GluR subunits or degradative products, as well as subunits incorporated into the outer cell membrane. GluR5/6/7 labeling was detected in fine punctate profiles in apical dendritcs that may represent some aggregated form of these subunits, although their identity has not been ascertained ultrastructurally as yet. Consistent with this finding, Jones and Baughman (1991) have demonstrated, with focal application of glutamate on cultured cortical neurons, that most GluRs are organized into "hot spots" along dendrites, rather than being diffusely distributed over the surface of the dendrite. While the present results demonstrated a more extensive dendritic labeling for GluR5/6/7 than GluR2/3, this pattern should be interpreted with caution as it may reflect differences in epitope availability or antibody avidity rather than differences in intracellular distribution.

\section{Functional implications for GluR subunit diversity}

Functional expression studies in Xenopus oocytes and mammalian cell lines have demonstrated that diverse agonist response propertics are clicited when AMPA/kainate- or kainateclass GluR subunits form homomeric or heteromeric receptor complexes (Hollman et al., 1989; Bettler et al., 1990, 1992; Boulter et al., 1990; Keinänen et al., 1990; Nakanishi et al., 
1990; Sommer et al., 1990, 1992; Egebjerg et al., 1991; Herb et al., 1992; Sommer and Seeburg, 1992). In addition, sequence variants of these subunits exist that may impart different channel properties. For instance, adjacent exons encode two alternative versions ("flip" and "flop") of the GluR1-GluR4 amino acid sequences in the region preceding the fourth transmembrane domain, and these variants impart different responses to AMPA and glutamate (Sommer et al., 1990; Sommer and Seeburg, 1992). In addition, $\mathrm{N}$ - and $\mathrm{C}$-terminal domain sequence variants of the kainate-class GluRs exist, which may also be regulated by alternative splicing (Bettler et al., 1990; Sommer et al., 1992). Further alternate forms of GluRs 2, 5, and 6 and 7 have also been identified, with the replacement of a glutamine residue with arginine in the second transmembrane domain, probably as a result of specific RNA editing (Hume et al., 1991; Sommer et al., 1991; Verdoorn et al., 1991; Sommer and Seeburg, 1992). This latter single amino acid alteration has been shown to result in changes in GluR2 channel properties, including decreased calcium permeability (Hume et al., 1991; Verdoorn et al., 1991; Sommer et al., 1992). Notably, the GluR2 subunit, in either its edited or unedited forms, functionally dominates channel characteristics when coexpressed with other kainate/AMPA subunits (Hollmann et al., 1991; Hume et al., 1991; Verdoorn et al., 1991; Sommer and Seeburg, 1992; Sommer et al., 1992).

These studies indicate that channels with unique properties may be constructed from heterogeneous GluR subunit proteins. A ncuron's content and combination of these different GluRs in their various isoforms are therefore likely to mediate its celltype-specific response to EAA-containing afferents and potentially confer a high degree of diversity and specificity on the postsynaptic component of glutamatergic circuits. Different neuronal subpopulations have been shown to have receptors that respond exclusively to either kainate or AMPA or to both AMPA and kainate (Robinson and Deadwyler, 1981; Westbrook and Lothman, 1983; Agrawal and Evans, 1986; Barnard and Henley, 1990; Huettner, 1990; Patneau and Mayer, 1991; Barnes and Henley, 1992), which presumably reflects the synaptic organization of the GluR subunits that they express. Such complements of receptor subunits may underlie the rapidly desensitizing, low-calcium-permeable responses generally identified with AMPA receptors and the slowly desensitizing, calciumpermeable responses of identified kainate responses (Patneau and Mayer, 1991). Furthermore, physiologically identified kainate-responding channels in different neurons vary in their calcium permeability (lino et al., 1990).

While our data do not allow for definitive statements as to which subunit combinations are present at the synapse, they do suggest that certain AMPA/kainate and kainate subunit combinations are possible for specific neuronal subpopulations within given neural circuits. In particular, the great majority of pyramidal neurons in the macaque prefrontal cortex contain immunoreactivity for AMPA/kainate (GluR1, GluR2/3) and kainate (GluR5/6/7) receptor-class subunits. Physiological studies in rat and guinea pig neocortex have indicated that nonNMDA receptors underlie the fast monosynaptic component of the EPSP in neocortical pyramidal neurons that arises from stimulation of thalamic or corticocortical pathways, whereas both non-NMDA and NMDA receptors may be involved in the slower, possibly polysynaptic, component of the EPSP (Jones and Baughman, 1988; Sutor and Hablitz, 1989; Hablitz and Sutor, 1990; Hirsch and Crepel, 1990; Higashi et al., 1991; McCormick, 1992; Zorumski and Thio, 1992). Furthermore,
non-NMDA antagonists reduce the subsequent IPSP observed on these neurons, supporting the proposition that some GABAergic interneurons may also contain the non-NMDA ionotropic GluRs.

The extent to which these phenotypic differences between neurons in the macaque prefrontal cortex regulate their response to EAA-containing afferents from the thalamus and other cortical areas remains to be established. Of interest are the comparatively few neurons that contain GluR5/6/7 immunoreactivity in the primary and secondary visual neocortical areas (Huntley et al., 1993). In contrast, a larger proportion of neurons in the prefrontal areas contain non-NMDA GluR subunits, which is likely to reflect the importance of this area as a polymodal association area receiving EAA-containing projections from multiple cortical areas (Goldman-Rakic, 1988). The distribution of GluR2/3 and GluRl immunoreactivity in monkey prefrontal cortex was very similar to that observed in the rat neocortex (Petralia and Wenthold, 1992), indicating that the rolc of these AMPA/kainate-class GluRs in receptor formation and EAA-containing pathways may be conserved within functionally distinct subgroups of cortical neurons in rat and primate.

\section{Implications for EAA-induced neurotoxicity and neurodegenerative diseases}

EAA neurotoxicity has been proposed to have a role in neuronal degeneration following ischemia, physical trauma, and seizure activity as well as in major human neurodegenerative diseases such as amyotrophic lateral sclerosis and Huntington's, Parkinson's, and Alzheimer's diseases (Choi, 1988, 1990; Greenamyre and Young, 1989; Choi and Rothman, 1990; Olney, 1990; Meldrum and Garthwaite, 1991). A common pathway underlying these phenomena may be elevated activity of specific GluKs leading to alterations in neuronal function and activation followed by degencration that can be attributed, to some degrec, to intracellular, calcium-activated, proteolytic pathways. A key feature is that selective subpopulations of neurons are affected, suggesting that a neuron's susceptibility to excitotoxicity is partly determined by the properties of the GluRs it expresses.

In Alzheimer's disease, it has been demonstrated that the subsets of cortical neurons that degenerate in response to the disease process are pyramidal neurons preferentially localized to particular layers of association cortex (Wilcock et al., 1982; Pearson et al., 1985; Braak and Braak, 1986; Lewis et al., 1987; Esiri et al., 1990; Hof et al., 1990). Furthermore, the subpopulation of neurons that contain the NF triplet proteins in the cortex have been shown to be particularly vulnerable to degeneration through formation of the hallmark neurofibrillary tangle in Alzheimer's disease (Morrison et al., 1987; Hof et al., 1990; Vickers et al., 1992), but that the degeneration of the NF tripletcontaining neurons may not be sufficient to account completely for the total loss of cells (Hof et al., 1990). As a site of major corticocortical interconnections, the association areas are likely to receive an abundance of EAA-containing inputs. Glutamate toxicity linked to calcium-activated processes in neurons has been linked with both degeneration and cytoskeletal alterations similar to those underlying neurofibrillary tangle formation (De Boni and McLachlan, 1985; Sautiére et al., 1991; Mattson et al., 1992). The selective distribution of particular GluRs that may mediate damage (e.g., subunit compositions that allow entry of calcium) may therefore explain why certain neurons in Alzheimer's disease are affected. Neurons that contain both a particular GluR complement and the NF triplet may therefore 
be rendered vulnerable to neurofibrillary tangle formation, whereas the neurons that contain the same subset of GluRs but not the NF triplet may degenerate without forming neurofibrillary tangles. Interactions between the GluR subunit and cytoskeletal profiles of neurons may also, in part, underlie the vulnerability of neurons to form the filamentous hallmarks characteristic of amyotrophic lateral sclerosis and Parkinson's disease. For example, experimental models have demonstrated that glutamate toxicity in rat spinal cord leads to NF accumulations in motor neurons that resemble what is observed in amyotrophic lateral sclerosis (Hugon and Vallat, 1990). In addition, it is possible that the potential vulnerability conferred by the presence of calcium-gating GluR subunits such as GluR6 within GABAergic interneurons is attenuated by the presence of a high levels of calcium-binding proteins in these interneurons relative to pyramidal cells.

Therefore, a neuron's complement of GluR subunits may render it more or less vulnerable to EAA-induced excitotoxicity, which supports the proposal that the intrinsic properties of particular subsets of neurons may determine how neurons respond to disease or other pathological processes (Vogt and Vogt, 1951; Morrison et al., 1990). The present results demonstrate that cortical projection neurons in the primate prefrontal cortex have a broad complement of non-NMDA GluR subunits that may contribute toward a sensitivity of these neurons to glutamateinduced damage. However, it is likely that a neuron's phenotypic composition of GluR subunits in combination with other neurochemicals, such as cytoskeletal and calcium-binding proteins, may further define how these neurons respond to pathological processes such as EAA neurotoxicity.

\section{Conclusions}

An expanding number of distinct GluR subunits appear to be involved in mediating EAA transmission in the nervous system. Further diversity in receptor subunits arises from alternatively spliced and RNA-edited subunit forms and the fact that different combinations of GluR subunits produce receptors with different response characteristics. The present multiple labeling results indicate that non-NMDA GluR subunits have a complex distribution within the primate neocortex with a principal localization to projection neurons and subpopulations of intrinsic neurons. The identification of the GluR complement of specific subpopulations of ncurons provides insight into the role of these neurons within EAA-mediated pathways and may also reveal crucial neurochemical characteristics that render subsets of neurons particularly vulnerable in a given neurodegenerative disorder.

\section{References}

Agrawal SG, Evans RH (1986) The primary afferent depolarizing action of kainate in the rat. Br J Pharmacol 87:345-355.

Barnard JM, Henley JM (1990) the non-NMDA receptors: types, protein structure and molecular biology. Trends Pharmacol Sci 11:504511.

Barnes JM, Henley JM (1992) Molecular characteristics of excitatory amino acid receptors. Prog Neurobiol 39:113-133.

Bettler B, Boulter J, Hermans-Borgmeyer I, O'Shea-Greenfield A, Deneris ES, Moll C, Borgmeyer U, Hollmann M, Heinemann S (1990) Cloning of a novel glutamate receptor subunit, GluR5: expression in the nervous system during development. Neuron 5:583-595.

Bettler B, Egebjerg J, Sharma G, Pacht G, Hermans-Borgmeyer I, Moll C, Stevens CF, Heinemann S (1992) Cloning of a putative glutamate receptor: a low affinity kainate-binding subunit. Neuron 8:257-265.

Boulter J. Hollmann M, O'Shea-Greenfield A, Hartley M, Deneris E,
Maron C, Heinemann S (1990) Molecular cloning and functional expression of glutamate receptor subunit gencs. Science 249:10331037.

Braak H, Braak E (1986) Ratio of pyramidal cells versus non-pyramidal cells in the human frontal isocortex and changes in ratio with ageing and Alzheimer's disease. In: Progress in brain research, Vol 70, The brain in aging and Alzheimer's disease (Swaab DF, Fliers E, Mirmiran M, van Gool WA, van Haaren F, eds), pp 185-212. Amsterdam: Elsevier.

Campbell MI, Morrison JH (1989) Monoclonal antibodies to neurofilament protein (SMI-32) labels a subpopulation of pyramidal neurons in the human and monkey neocortex. J Comp Neurol 282:191205.

Choi DW (1988) Glutamate neurotoxicity and diseases of the nervous system. Neuron 1:623-634.

Choi DW (1990) Cerebral hypoxia: some new approaches and unanswered questions. J Neurosci 10:2493-2501.

Choi DW, Rothman SM(1990) The role of glutamate neurotoxicity in hypoxic-ischemic neuronal death. Annu Rev Neurosci 13:171-182.

De Boni U, Crapper McLachlan DR (1985) Controlled induction of paired helical filaments of the Alzheimer type in cultured human neurons, by glutamate and aspartate. J Neurol Sci 68:105-118.

DeFelipe J, Hendry SHC, Jones EG (1989a) Synapses of double bouquet cells in monkey cerebral cortex visualized by calbindin immunoreactivity. Brain Res 503:49-54.

DeFelipe J, Hendry SHC, Jones EG (1989b) Visualization of chandelier cell axons by parvalbumin immunoreactivity in monkey cerebral cortex. Proc Natl Acad Sci USA 86:2093-2097.

Egebjerg J, Bettler B, Hermans-Borgmeyer I, Heinemann S (1991) Cloning of a cDNA for a glutamate receptor subunit activated by kainate but not AMPA. Nature 351:745-748.

Esiri MM, Pearson RCA, Steele JE, Powell TPS (1990) A quantitative study of the neurofibrillary tangles and the choline acetyltransferase activity in the cerebral cortex and the amygdala and Alzheimer's disease. J Neurol Neurosurg Psychiatry 53:161-165.

Goldman-Rakic PS (1988) Topography of cognition: parallel distributed networks in primate association cortex. Annu Rev Neurosci 11 : $137-156$.

Greenamyre JT, Young AB (1989) Excitatory amino acids and Alzheimer's disease. Neurobiol Aging 10:593-602.

Hablitz JJ, Sutor B (1990) Excitatory postsynaptic potentials in rat neocortical neurons in vitro. III. Effects of a quinoxalinedione nonNMDA receptor antagonist. J Neurophysiol 64:1282-1290.

Hendry SHC, Jones EG, Emson PC, Lawson DEM, Heizmann CW, Streit P (1989) Two classes of cortical GABA neurons defined by differential calcium binding protein immunoreactivities. Exp Brain Kes 76:467-472.

Herb A, Burnashev N, Werner P, Sakmann B, Wisden W, Seeburg PH (1992) The KA-2 subunit of excitatory amino acid receptors show widespread expression in brain and forms ion channels with distantly related subunits. Neuron $8: 775-785$.

Higashi H, Tanaka E, Nishi S (1991) Synaptic responses of guinea pig cingulate cortical neurons in vitro. J Neurophysiol 65:822-833.

Hirsch JC, Crepel F (1990) Use-dependent changes in synaptic efficiency in rat prefrontal neurons in vitro. J Physiol (Lond) 427:31-49.

Hof PR, Cox K, Morrison JH (1990) Quantitative analysis of a vulnerable subset of pyramidal neurons in Alzheimer's disease. I. Superior frontal and inferior temporal cortex. J Comp Neurol 301:4454.

Hollmann M, O'Shea-Greenfield A, Rogers SW, Heinemann S (1989) Cloning by functional expression of a member of the glutamate receptor family. Nature 342:643-648.

Hollmann M, Hartley M, Heinemann S (1991) $\mathrm{Ca}^{2+}$ permeability of KA-AMPA-gated glutamate receptor channels depends on subunit composition. Science 252:851-853.

Huettner JE (1990) Glutamate receptor channels in rat DRG ncurons: activation by kainate and quisqualate and blockade of desensitization by Con A. Neuron 5:255-266.

Hugon J, Vallat JM (1990) Abnormal distribution of phosphorylated neurofilaments in neuronal degeneration induced by kainic acid. Neurosci Lett 1 19:45-48.

Hume RI, Dingledine R, Heinemann SF (1991) Identification of a site in glutamate receptor subunits that controls calcium permeability. Science 253:1028-1031.

Huntley GW, Rogers SW, Moran T, Janssen W, Archin N, Vickers JC, 
Heinemann SH, Morrison JH (1993) Selective distribution of kainate receptor subunit immunoreactivity in monkey neocortex revealed by a monoclonal antibody which recognizes glutamate receptor subunits GluR5/6/7. J Neurosci 13:2965-2981.

Iino M, Ozawa S, Tsuzuki K (1990) Permeation of calcium through excitatory amino acid receptor channels in cultured rat hippocampal neurones. J Physiol (Lond) 424:151-165.

Jones KA, Baughman RW (1988) NMDA- and non-NMDA-receptor components of excitatory synaptic potentials recorded from cells in layer $\mathrm{V}$ of rat visual cortex. J Neurosci 8:3522-3534.

Jones KA, Baughman RW (1991) Both NMDA and non-NMDA subtypes of glutamate receptors are concentrated at synapses on cerebral cortical neurons in culture. Neuron 7:593-603

Keinänen K, Wisden W, Sommer B, Werner P, Herb A, Verdoorn TA, Sakmann B, Seeburg PH (1990) A family of AMPA-selective glutamate receptors. Science 249:556-560.

Lee VM-Y, Otvos L, Carden MJ, Hollosi M, Dietzschold B, Lazzarini RA (1988) Identification of the major multiphosphorylation site in mammalian neurofilaments. Proc Natl Acad Sci USA 85:1998-2002.

Lewis DA, Campbell MJ, Terry RD, Morrison JH (1987) Laminar and regional distributions of neurofibrillary tangles and neuritic plaques in Alzheimer's disease: a quantitative study of visual and auditory cortices. J Neurosci 7:1799-1808.

Mattson MP, Cheng B, Davis D, Bryant K, Lieberburg I, Rydel RE (1992) $\beta$-Amyloid peptides destabilize calcium homeostasis and render human cortical neurons vulnerable to excitotoxicity. J Neurosci $12: 376-389$

McCormick DA (1992) Neurotransmitter actions in the thalamus and cerebral cortex and their role in neuromodulation of thalamocortical activity. Prog Neurobiol 39:337-388.

Meldrum B, Garthwaite J (1991) Excitatory amino acid neurotoxicity and neurodegenerative disease. Trends Pharmacol Sci 11:54-61.

Morrison JH, Lewis DA, Campbell MJ, Huntley GW, Benson DL, Bouras C (1987) A monoclonal to non-phosphorylated neurofilament protein marks the vulnerable cortical neurons in Alzheimer's disease. Brain Res 416:331-336.

Morrison JH, Hof PR, Campbell MJ, De Lima AD, Voigt T, Bouras C, Cox K, Young WG (1990) Cellular pathology in Alzheimer's disease: implications for corticocortical disconnection and differential vulnerability. In: Imaging, cerebral topography and Alzheimer's disease (Rapoport SR, Petit H, Leys D, Christen Y, eds), pp 19-40. Berlin: Springer.

Nakanishi N, Shneider NA, Axel R (1990) A family of glutamate receptor genes: evidence for the formation of heteromultimeric receptors with distinct channel properties. Neuron 5:569-581.

Olney JW (1990) Excitotoxin-mediated neuron death in youth and old age. In: Progress in brain research, Vol 86, Molecular and cellular mechanisms of neuronal plasticity in normal aging and Alzheimer's disease (Coleman P, Higgins G, Phelps C, eds), pp 37-51. Amsterdam: Elsevier.

Patneau DK, Mayer ML (1991) Kinetic analysis of interactions between kainate and AMPA: evidence for activation of a single receptor in mouse hippocampal neurons. Neuron 6:785-798.

Pearson RCA, Esiri MM, Hiorns RW, Wilcock GK, Powell TPS (1985) Anatomical correlates of the distribution of pathological changes in the neocortex in Alzheimer's disease. Proc Natl Acad Sci USA 82: $4531-4534$.
Peters A, Sethares C (1991) Organization of pyramidal neurons in area 17 of monkey visual cortex. J Comp Neurol 306:1-23.

Petralia RS, Wenthold RJ (1992) Light and electron immunocytochemical localization of AMPA-selective glutamate receptors in the rat brain. J Comp Neurol 318:329-354.

Robinson JH, Deadwyler SA (1981) Kainic acid produces depolarization of CA3 pyramidal cells in the in vitro hippocampal slice. Brain Res 221:117-127.

Sautiére P-E, Sindou P, Couratier P, Hugin J, Wattez A, Delacourte A (1992) Tau antigenic changes induced by glutamate in rat primary culture model: a biochemical approach. Neurosci Lett 140:206-210.

Sommer B, Seeburg PH (1992) Glutamate receptor channels: novel properties and new clones. Trends Pharmacol Sci 13:291-296.

Sommer B, Keinänen K, Verdoorn TA, Wisden W, Burnashev N, Herb A, Köhler M, Takagi T, Sakmann B, Seeburg PH (1990) Flip and flop: a cell-specific functional switch in glutamate-operated channels of the CNS. Science 249:1580-1585.

Sommer B, Köhler M, Sprengel R, Seeburg PH (1991) RNA editing in brain controls a determinant or ion flow in glutamate-gated channels. Cell 67:11-19.

Sommer B, Burnashev N, Verdoon TA, Keinänen K, Sakmann B, Seeburg PH (1992) A glutamate receptor channel with high affinity for domoate and kainate. EMBO J 11:1651-1656.

Sternberger LA, Sternberger NH (1983) Monoclonal antibodies distinguish phosphorylated and non-phosphorylated forms of neurofilaments in situ. Proc Natl Acad Sci USA 80:6126-6130.

Stollberg J, Berg DK (1987) Neuronal acetylcholine receptors: fate of surface and internal pools in cell culture. J Neurosci 7:1809-1815.

Sutor B, Hablitz JJ (1989) EPSPs in rat neocortical neurons in vitro II. Involvement on $N$-methyl-D-aspartate receptors in the generation of EPSPs. J Neurophysiol 61:621-634.

Verdoorn TA, Burnashev N, Monyer H, Seeburg PH, Sakmann B (1991) Structural determinants of ion flow through recombinant glutamate receptor channels. Science 252:1715-1718.

Vickers JC, Delacourte A, Morrison JH (1992) Progressive transformation of the cytoskeleton associated with normal aging and $\mathrm{Al}$ zheimer's disease. Brain Res 594:273-278.

Vogt C, Vogt O (1951) Importance of neuroanatomy in he field of neuropathology. Neurology 1:205-218.

Wenthold RJ, Hunter C, Wada K, Dechesne CJ (1990) Antibodies to a C-terminal peptide of the rat brain glutamate receptor subunit GluR-A, recognize a subpopulation of AMPA binding sites but not kainate sites. FEBS Lett 276:147-150.

Wenthold RJ, Yokotani N, Doi K, Wada K (1992) Immunochemical characterization of the non-NMDA glutamate receptor using subunitspecific antibodies. J Biol Chem 267:501-507.

Werner P, Voigt M, Keinänen K, Wisden W, Seeburg PH (1991) Cloning of a putative high-affinity kainate receptor expressed predominately in hippocampal CA3 cells. Nature 351:742-744.

Westbrook GL, Lothman EW (1983) Cellular and synaptic basis of kainic acid-induced hippocampal epileptiform activity. Brain Res 273:97-109.

Wilcock GK, Esiri MM (1982) Plaques, tangles and dementia. J Neurol Sci 56:343-356.

Zorumski CF, Thio LL (1992) Properties of vertebrate glutamate receptors: calcium mobilization and desensitization. Prog Neurobiol 39:295-336. 